\title{
ANALISIS PENGARUH REWARD DAN PUNISHMENT TERHADAP MOTIVASI PEGAWAI DI PUSAT PENDIDIKAN DAN PELATIHAN PERDAGANGAN
}

\author{
Tien Danarti Mesra* \\ Pusat Pendidikan dan Pelatihan Perdagangan \\ *Corresponding author \\ Email : danti_wiyono@yahoo.com
}

\begin{abstract}
Abstrak
Melayani, adalah misi organisasi pemerintah yang meniadi salah satu ciri pembeda dengan organisasi swasta yang berorientasi untuk menghasilkan keuntungan. Saat ini, di era yang demikian kompetitif, masyarakat membutuhkan pelayanan yang cepat, tepat, ramah dan profesional. Hal ini akan terwujud bila setiap sumber daya manusia di dalam organisasi pemerintah memahami tugas dan fungsinya masingmasing, memiliki motivasi untuk melayani dan fokus untuk memberikan kinerja yang optimal untuk mencapai tujuan bersama. Mengacu dari keadaan tersebut, menunjukkan bahwa sumber daya manusia tetap menjadi kunci utama bagi keberhasilan organisasi pemerintah dalam memberikan pelayanan kepada masyarakat. Pentingnya peran sumber daya manusia tersebut menuntut manaiemen pada organisasi pemerintah untuk berstrategi bagaimana cara mengelola, mengembangkan, memelihara dan mendayagunakan mereka agar dapat berkontribusi seara optimal terhadap organisasi. Salah satu metode yang sering digunakan dalam mengelola sumber daya manusia adalah melalui penerapan reward dan punishment. Penelitian ini bertujuan untuk menganalisis dan menggambarkan efektifitas antara pemberian reward dengan penerapan punishment terhadap motivasi pegawai di Pusat Pendidikan dan Pelatihan Perdagangan, Metode penelitian yang digunakan adalah analisis deskriptif dengan pendekatan kuantitatif, dilatar belakangi oleh tujuan menjelaskan mengenai pengaruh variabel-variabel yang hendak diteliti dan kemudian menguji hipotesis yang telah dirumuskan sebelumnya. Variabel penelitian adalah variabel reward (X1), variabel punishment (X2) sebagai variabel yang mempengaruhi dan variabel motivasi (Y) sebagai variabel yang dipengaruhi. Metode pengumpulan data yang digunakan adalah menyebarkan kuesioner dan mencatat dokumen-dokumen. Analisis data dalam penelitian ini menggunakan analisis regresi linear sederhana yang diolah dengan menggunakan excel. Hasil yang didapat dari penelitian ini adalah variabel reward (X1) memiliki pengaruh yang signifikan terhadap variabel motivasi (Y), sebaliknya variabel punishment (X2) kurang berpengaruh terhadap variabel motiv asi ( $Y$ ).
\end{abstract}

Kata Kunci : Reward, Punishment, Motivasi

\begin{abstract}
Serving, is the mission of government organizations which is one of the distinguishing characteristics of private organizations that are profit-oriented. Today, in such a com petitive era, people need fast, precise, friendly, and professional services. This will be realized if every hum an resource in government organizations understands their respective duties and functions, has the motivation to serve and focuses on providing optimal perform ance to achieve common goals. Referring to this situation, it shows that hum an resources rem ain as the main key for the success of governm ent organizations in providing services to the community. The im portance of the role of hum an resources requires m anagem ent in governm ent organizations to have a strategy on how to manage, develop, maintain, and utilize them so that they can contribute optim ally to the organization. One method that is often used in managing hum an resources is through the application of reward and punishment. The research method used is descriptive analysis with a quantitative approach, with the background of the objective is to explain the influence of the variables to be studied and then testing the hypotheses that have been formulated previously. The research variables are the reward variable (X1), the punishm ent variable (X2) as the influencing variable and the motivation variable (Y) as the influenced variable. The data collection method used was by distributing questionnaires and record documents. Analysis of the data in this study using multiple linear regression analysis processed using excel
\end{abstract}


program. The results obtained from this study are the reward variable (XI) has a significant effect on the motivation variable (Y), on the other hand, the punishment variable (X2) has less effect on the motivation variable (Y).

Keywords: Reward, Punishment, Motivation

(C) 2020 Pusdiklat Perdagangan. All rights reserv ed

\section{PENDAHULUAN}

\section{Latar Belakang}

Membahas tentang reward dan punishment selalu menggiring ke terjadinya perbedaan pandangan, mana yang seharusnya lebih didahulukan diantara keduanya. Selama ini para pegawai di lingkungan Kementerian/Lembaga lebih mengenal adanya punishment atau sanksi daripada reward. Sanksi, yang lebih dikenal dengan istilah 'hukuman disiplin' tersebut ditetapkan secara jelas mengacu dari Peraturan Pemerintah Nomor 53 Tahun 2010 tentang Disiplin Pegawai Negeri Sipil dan turunannya yaitu Peraturan Kepala Badan Kepegawaian Negara Nomor 21 Tahun 2010 tentang Ketentuan Pelaksanaan Peraturan Pemerintah Nomor 53 Tahun 2010 tentang Disiplin Pegawai Negeri Sipil. Sebaliknya, tidak ada peraturan yang mengatur secara khusus tentang pemberian reward (penghargaan) kepada ASN, dengan kata lain implementasi pemberian reward diserahkan kepada masing-masing Kementerian/Lembaga sesuai dengan kebijakan internal yang ada. Aturan mengenai reward hanya muncul pada sebuah pasal dalam Undang-undang No.5 Tahun 2014, tentang Aparatur Sipil Negara (ASN), yaitu di Pasal 82 yang menyebutkan bahwa, "Pegawai Negeri Sipil (PNS) yang telah menunjukkan kesetiaan, pengabdian, kecakapan, kejujuran, kedisiplinan, dan prestasi kerja dalam melaksanakan tugasnya, dapat diberikan penghargaan atau reward.

Dikatakan Tohardi (2002:317), bahwa penghargaan aalah ganjaran yang diberikan untuk memotivasi para karyawan agar produktivitasmya tinggi. Keterkaitan antara penghargaan dan motivasi juga disampaikan oleh Mulyadi dan Setyawan (2001:227) bahwa sistem penghargaan merupakan salah satu alat pengendali penting yang digunakan oleh perusahaan untuk memotivasi personelnya agar mencapai tujuan perusahaan dengan perilaku sesuai dengan yang diharapkan perusahaan. Senada dengan pendapat kedua pakar di atas, Sastrohadiwiryo (2002:269), mengemukakan unsur-unsur penggerak motivasi, antara lain: 1. Kinerja (Achievement); $2 . \quad$ Penghargaan (Appreciation); 3. Tantangan (Challenge); 4. Tanggungjawab (Responsibility); 5. Pengembangan (Development); 6. Keterlibatan (Involvement); 7. Kesempatan (Opportunity). Beberapa pendapat ahli di atas menjelaskan bahwa sesungguhnya metode pemberian penghargaan merupakan salah satu unsur penggerak motivasi yang dapat mempengaruhi kinerja individu dalam suatu organisasi. Apabila makna dari pernyataan tersebut didalami, maka manusia sebagai unsur utama yang berperan penting dalam menggerakkan roda organisasi perlu dikelola secara profesional oleh manajemen agar termotivasi dalam melakukan pekerjaannya yang berujung pada tercapainya tujuan organisasi. Tak heran jika dikatakan bahwa keberhasilan organisasi sangat ditentukan oleh bagaimana manajemen mengelola sumber daya manusianya. Sikap obyektif dan netral dari manajemen sangat dibutuhkan, bahkan pada saat organisasi menyusun kebijakan internalnya. Idealnya ketentuan apapun yang diterbitkan seharusnya tidak mengganggu semangat pegawai dalam berkinerja dan meraih prestasi. Manajemen harus mampu menjaga kondusifitas di antara pegawai, sehingga setiap tugas dapat dilaksanakan sesuai aturan dan pegawai dapat memberikan kontribusi secara maksimal terhadap pencapaian tujuan organisasi.

Salah satu keadaan yang bisa dijadikan acuan bagi manajemen dalam mengawasi kinerja pegawai adalah dengan mengenali respon pegawai terhadap kondisi yang mempengaruhi pekerjaan mereka. Adanya tanda-tanda ketidakpuasan yang terungkap dalam bentuk permintaan turn over (perpindahan), ketidakhadiran dan bentuk pelanggaran disiplin lain yang dilakukan oleh pegawai merupakan indikator kuat adanya 
ketidakpuasan dalam bekerja yang memicu turun atau hilangnya motivasi pegawai. Seperti dikemukakan Siagian dalam As'ad (2004) bahwa beberapa bentuk dari ketidakpuasan kerja yaitu : 1. Labor turn over pindahnya pegawai yang tinggi 2. Sering terjadinya pertikaian perburuhan, yang dapat mengakibatkan pemogokan 3. Terlalu banyak pegawai yang tidak masuk atau sering terlambat 4. Moral kerja yang rendah berupa kemalasan 5. Apatisme. Pendapat lain adalah dari Mobley et. al dalam Vera dan Bagus (2017) proses terjadinya intention turnover karyawan diawali oleh munculnya ketidakpuasan karyawan terhadap pekerjaannya. Ketidakpuasan terhadap pekerjaan tersebut kemudian memunculkan intention turnover berupa pikiran untuk keluar dari perusahaan, niatan untuk mencari pekerjaan lain, serta niatan untuk keluar dari perusahaan.

Namun, turunnya motivasi pegawai tidak mesti disebabkan oleh rasa tidak puas mereka terhadap lingkungan kerja saja, tapi bisa juga disebabkan oleh ketidakcocokan terhadap pendekatan kepemimpinan yang sedang berlangsung, atau bisa juga disebabkan oleh tidak adanya sistem reward yang dapat mengakomodir kebutuhan mereka, atau mungkin karena kurang efektifnya sistem punishment yang diterapkan, sehingga mereka cenderung masa bodoh dan meremehkan sanksi yang akan diterima.

Uraian di atas relevan dengan kondisi yang terjadi di Pusdiklat Perdagangan saat ini yang mana penerapan punishment terlihat lebih dominan bila dibandingkan dengan penerapan reward. Mengapa demikian? Dengan ditetapkannya Peraturan Pemerintah Nomor 53 Tahun 2010 tentang Disiplin Pegawai Negeri Sipil dan turunannya yaitu Peraturan Kepala Badan Kepegawaian Negara Nomor 21 Tahun 2010 tentang Ketentuan Pelaksanaan Peraturan Pemerintah Nomor 53 Tahun 2010, maka Kementerian/Lembaga lebih jelas dan mudah dalam menjalankan isi pasal demi pasal peraturan tersebut karena adanya batasan dan tolok ukur yang jelas dalam pengenaan hukumannya. Namun apakah keterukuran tersebut serta merta dapat menggambarkan efektif atau tidaknya peraturan tersebut diterapkan, tentu saja jawabannya adalah belum tentu. Berdasarkan data di Bagian Kepegawaian Pusdiklat Perdagangan (Desember, 2019), terdapat 7 (tujuh) pegawai yang melakukan pelanggaran disiplin sehingga mendapatkan teguran ringan sampai berat hingga salah satu diantaranya memperoleh sanksi 'penundaan Kenaikan Gaji Berkala (KGB)'. Dari sumber yang sama (Oktober, 2020), tiga dari para pegawai pelanggar disiplin tersebut mengulang pelanggaran yang sama, dan mengakibatkan salah satu diantaranya akan mendapatkan sanksi 'pemberhentian dengan hormat tidak atas permintaan sendiri'. Tidak adanya perubahan perilaku dari para pegawai pelanggar disiplin tersebut, rendahnya motivasi mereka untuk memperbaiki perilaku dan kinerja, serta ketidakperdulian mereka terhadap sanksi yang akan mereka terima sesungguhnya merupakan kondisi riil yang dapat digunakan untuk meneliti sampai sejauh mana sebenarnya efektifitas dari penerapan punishment itu sendiri.

Agak berbeda dengan punishment, pelaksanaan reward di lingkungan Kementerian Perdagangan belum seluruhnya bisa diterapkan secara konkrit dan kontinyu. Konteks konkrit di sini adalah belum semua kegiatan terkait reward secara nyata terbukti memberikan dampak terhadap karier pegawai. Sedangkan belum kontinyu karena sejauh ini belum ada aturan/payung hukum yang mengatur agar unit/satker di lingkungan Kementerian Perdagangan dapat mengimplementasikan reward secara rutin setiap tahunnya bagi seluruh pegawai dari level bawah sampai pucuk pimpinan. Meskipun beberapa kegiatan terkait bidang kepegawaian yang telah diinisiasi oleh Biro Organisasi dan Kepegawaian merupakan implementasi dari reward, misalnya pemilihan Pegawai Berprestasi, namun kegiatan tersebut baru dilaksanakan satu kali di tahun 2019. Sedangkan untuk jenis reward lain seperti pemberian beasiswa S2 hanya diperuntukkan bagi pegawai yang memenuhi syarat tertentu, sehingga belum menjangkau ke seluruh pegawai.

Di Pusdiklat Perdagangan sendiri sampai saat ini belum memiliki kegiatan terkait reward 
meski dalam skala kecil. Hal ini terjadi mungkin diakibatkan tidak adanya kewajiban bagi instansi Kementerian/Lembaga untuk menyelenggarakan sistem penerapan reward, sehingga biasanya unit-unit berada dalam lingkungannya juga melakukan hal yang sama. Kedua, untuk menerima reward biasanya ada persyaratan kompetensi yang harus dipenuhi sehingga reward dianggap hanya mengakomodir kalangan tertentu saja. Misal, seleksi untuk "Pegawai Berprestasi" mensyaratkan bahwa wakil yang dikirim oleh unit harus memiliki ide inovasi dan harus menguasai substansi perdagangan. Jika reward dan punishment dikatakan sebagai metode yang begitu penting untuk menggerakkan motivasi, membentuk dan memperbaiki pribadi seseorang dalam suatu organisasi, mengapa hanya punishment yang diatur secara khusus dengan payung hukum tersendiri.

Sejumlah penelitian tentang reward dan punishment biasanya menghasilkan kesimpulan bahwa terdapat pengaruh signifikan keduanya terhadap motivasi ataupun kinerja pegawai. Suatu kesimpulan yang wajar, mengingat pembahasan tentang 'reward dan punishment' iibarat berbicara tentang dua sisi mata vang, yaitu tentang suatu metode untuk tujuan yang sama namun melalui pendekatan yang berbeda. Jika punishment menghasilkan efek jera, maka reward akan menghasilkan efek sebaliknya yaitu ketauladanan. Namun, hasil kesimpulan yang "sudah biasa" tersebut pada akhirnya menjadi keingintahuan penulis, apakah benar keduanya secara signifikan memang mempengaruhi motivasi ataupun kinerja pegawai, mengingat bahwa di Kementerian Perdagangan khususnya di Pusdiklat Perdagangan telah terjadi kasus pelanggaran disiplin yang berulang di dua tahun terakhir yang dilakukan oleh orang yang sama. Pada akhirnya gambaran kondisi di atas menjadi gagasan utama yang melatarbelakangi penulisan makalah ini.

\section{Tujuan dan Manfaat}

Tujuan penulisan secara umum adalah untuk:
1. menganalisa pengaruh pemberian reward (X1) terhadap motivasi pegawai (Y) di Pusdiklat Perdagangan

2. menganalisa pengaruh penerapan punishment (X2) terhadap motivasi pegawai $(Y)$ di Pusdiklat Perdagangan.

3. Menganalisa mana yang lebih tepat antara pemberian reward atau penerapan punishment dalam memotivasi pegawai di Pusdiklat Perdagangan

Sedangkan manfaat penulisan adalah untuk memberikan rekomendasi kepada manajemen yang menangani sumber daya manusia di lingkungan internal Pusdiklat Perdagangan maupun manajemen di instansi Pusat terhadap permasalahan yang timbul akibat pelanggaran yang dilakukan oleh pegawai Kementerian Perdagangan khususnya di Pusdiklat Perdagangan.

\section{Kajian Teori}

\section{Konsep Reward dan Punishment}

Reward dan Punishment, merupakan dua bentuk metode yang dikenal dalam bidang manajemen sebagai cara untuk memotivasi seseorang agar lebih baik dalam berperilaku dan berkinerja. Bersifat seperti dua sisi mata vang, dalam pembahasan keduanya selalu muncul bersama-sama sebagai suatu istilah yang mengarah kepada tindakan yang digunakan manajemen dalam mengelola perilaku sumber daya manusianya. Dalam konsep manajemen sumber daya manusia, reward merupakan salah satu alat untuk meningkatkan motivasi para pegawai. Metode ini dianggap bisa mengintervensi perbuatan dan kelakuan seseorang melalui perasaan bahagia, senang, sehingga membuat mereka melakukan suatu perbuatan yang baik secara berulang-ulang. Seperti yang dikatakan (Nugroho, 2006) reward adalah ganjaran, hadiah, penghargaan atau imbalan yang bertujuan agar seseorang menjadi lebih giat usahanya untuk memperbaiki atau meningkatkan kinerja yang sudah dicapai. Menurut (Manullang 1996), reward merupakan suatu sarana motivasi atau sarana yang dapat menimbulkan dorongan dan merupakan salah satu jenis penghargaan yang dikaitkan dengan prestasi kerja, yang diberikan dalam 
bentuk uang atau penghargaan yang ditetapkan berdasarkan prestasi, semakin tinggi prestasi kerjanya, semakin besar pula reward yang diberikan. Handoko (1995), mengemukakan bahwa reward merupakan suatu alat untuk meningkatkan produktifitas kerja karyawan dan perilaku seseorang sehingga dapat mempercepat pelaksanaan pekerjaan yang dibebankan dan akhirnya target atau tujuan yang ingin dicapai terlaksana dengan baik. Sedangkan menurut Arikunto (1993), reward adalah sesuatu yang diberikan kepada seseorang karena sudah mendapatkan prestasi dengan yang dikehendaki. Keempat pernyataan dari para pakar manajemen di atas menunjukkan bahwa segala sesuatu yang diberikan organisasi untuk memuaskan satu atau beberapa kebutuhan individu disebut sebagai penghargaan atau reward.

Sistem reward yang ditetapkan oleh suatu organisasi biasanya mengacu dari nilai-nilai usaha, ketrampilan, kontribusi dan tanggung jawab mereka terhadap pencapaian tujuan organisasi. Merangkum pendapat para ahli tersebut bahwa reward merupakan sebuah bentuk pengakuan kepada suatu prestasi tertentu yang diberikan dalam bentuk material dan non material yang diberikan oleh pihak organisasi atau lembaga kepada individu atau kelompok pegawai agar mereka dapat bekerja dengan motivasi yang tinggi dan berprestasi dalam mencapai tujuan organisasi.

Menurut Long dalam (Irianto, 2001), jenis reward dikelompokkan menjadi 2 kategori, yaitu, 1) Penghargaan Intrinsik (instrinsic reward), adalah sesuatu yang dirasakan langsung oleh seseorang ketika dirinya melakukan sesuatu, atau dapat diartikan sebagai penghargaan yang diterima seseorang untuk dirinya sendiri. Biasanya reward ini merupakan nilai positif seseorang yang muncul atas pekerjaan dan tanggung jawab yang berhasil diselesaikannya, atau bisa juga merupakan kebanggaan yang timbul karena menjadi bagian dari organisasi perusahaan yang memiliki reputasi baik, adanya peningkatan kepercayaan diri dan sebagainya. 2). Penghargaan Ekstrinsik (extrinsic rewards) Penghargaan ekstrinsik adalah segala sesuatu yang akan diterima oleh seseorang dari lingkungan tempat dia bekerja dimana sesuatu yang diperolehnya tersebut sesuai dengan harapannya. Umumnya penghargaan ini bersifat nyata dan dibedakan menjadi: a). penghargaan langsung, misalnya tunjangan, bonus, pembagian laba perusahaan; b). penghargaan tidak langsung, seperti jaminan sosial, asuransi, pensiun, pesangon, pelatihan dan liburan, serta c). penghargaan non financial seperti promosi jabatan, lingkungan kerja yang nyaman, pengembangan diri ataupun fasilitas lain.

Pada dasarnya pengelolaan sistem reward dalam organisasi memiliki tujuan penting yaitu untuk menarik dan mempertahankan sumber daya manusia yang ada karena organisasi membutuhkan mereka untuk mencapai sasarannya. Seperti yang dikatakan (Ivancevich et al., 2006), tujuan utama dari program reward adalah a). Menarik orang yang memiliki kualifikasi untuk bergabung dengan organisasi. b). Mempertahankan karyawan agar terus datang untuk bekerja. c). Mendorong karyawan untuk mencapai tingkat kinerja yang tinggi. Namun ada yang lebih penting dari sekedar terapainya tujuan reward di atas, yaitu konsistensi penerapan reward itu sendiri Tentunya konsistensi implementasinya sangat dipengaruhi oleh peran dari masingmasing pimpinan, mulai dari pimpinan teratas sampai dengan pimpinan di unit kerja terkecil. Bentuk reward yang paling murah dan mudah dilakukan adalah apresiasi atau pujian. Sudahkan para pimpinan terbiasa dalam memberikan apresiasi kepada karyawan yang menunjukan perilaku positif yang diharapkan organisasi? Sekadar ucapan "Terimakasih atas kerja kerasnya" atau "Good job, saya suka semangat kamu." Meski simpel, namun bentuk apresiasi ini sangat murah dan mudah untuk dikerjakan, dan biasanya akan menimbulkan dampak positif cukup besar yang dirasakan pegawai sehingga perilaku positif merekapun akan diulang dan terpelihara.

Secara alamiah manusia memiliki kecenderungan untuk memilih berperilaku yang akan memberikan dampak positif pada dirinya, serta akan berusaha menjauhi perilaku yang bisa memberikan dampak negatif pada dirinya. Namun, sebagai individu manusia 
tentu memiliki sifat yang berbeda-beda. Seperti dikemukakan oleh Gregor. MC (1988) dalam (Hasibuan, 1996) dengan asumsi teori $X$ dan teori $Y$. Asumsi teori $X$ berisi tentang sifatsifat negatif individu misalnya tidak suka bekerja, tidak ambisius, tidak kreatif dan malas, sedangkan asumsi teori $\mathrm{Y}$ berisi tentang sifatsifat positif individu misalnya semangat bekerja, memiliki ambisi kearah lebih baik, kreatif dan rajin. Positif di pikiran seseorang belum tentu posititf di pikiran yang lainnya, demikian juga sebaliknya. Sebagai usaha untuk meminimalkan sifat-sifat $X$ tersebut maka manajemen atau pimpinan memberikan arahan, paksaan, punishment dan membuat aturan agar perilaku negatif tersebut tidak menghambat perusahaan dalam mencapai tujuannya dan kinerja dapat berjalan maksimal. Arahan diberikan untuk pelanggaran yang tidak terlampau berat, sebaliknya punishment biasanya diberikan untuk pelanggaran yang dinilai sudah cukup berat. Namun benarkah hal tersebut dapat berjalan efektif, mengingat punishment ternyata tidak membuat mereka termotivasi untuk memperbaiki kesalahannya. Seperti dikatakan oleh (Mangkunegara, 2000), punishment adalah ancaman hukuman yang bertujuan untuk memperbaiki kinerja karyawan pelanggar, memelihara peraturan yang berlaku dan memberikan pelajaran kepada pelanggar. Jika reward diharapkan dapat memotivasi seseorang supaya giat dalam menjalankan tanggung jawabnya dan pegawai akan lebih bekerja maksimal, maka punishment ditetapkan agar pegawai yang melakukan kesalahan dan pelanggaran dapat termotivasi untuk menghentikan perilaku menyimpang dan mengarahkan pada perilaku positif.

(Ivancevich et al., 2006) mendefinisikan punishment sebagai tindakan menyajikan konsekuensi yang tidak menyenangkan atau tidak diinginkan sebagai hasil dari dilakukanya perilaku tertentu. Sementara (Roestiyah, 1986) berpendapat bahwa punishment (hukuman) adalah suatu perbuatan yang tidak menyenangkan dari orang yang lebih tinggi kedudukannya untuk pelanggaran dan kejahatan, yang bermaksud untuk memperbaiki kesalahan anak dan bukan untuk mendendam. Dari pendapat para ahli di atas, menunjukkan bahwa ada tiga fungsi penting dari punishment yang berperan besar bagi pembentukan tingkah laku yang diharapkan: 1. Membatasi perilaku. 2. Bersifat mendidik. 3. Memperkuat motivasi untuk menghindarkan diri dari tingkah laku yang tidak diharapkan.

Memperhatikan uraian di atas, meskipun antara punishment dan reward seolah memiliki arti berlawanan, tetapi pada hakekatnya sama-sama bertujuan agar seseorang menjadi lebih baik. Selain itu meski penerapan reward dan punishment belum tentu berdampak signifikan terhadap peningkatan motivasi para pegawai, namun keduanya tetap dianggap sebagai metode bagi manajemen dalam mengelola kinerja sumber daya manusianya. Apabila dikaji lebih dalam penerapan reward dan punishment secara konsisten dapat membawa pengaruh positif, antara lain: 1. Mekanisme dan sistem kerja di suatu organisai menjadi lebih baik, karena adanya tolok ukur kinerja yang jelas; 2. Kinerja individu dalam suatu organisasi semakin meningkat, karena adanya sistem pengawasan yang obyektif dan tepat sasaran, dan 3. Adanya kepastian indikator kinerja yang menjadi ukuran kuantitatif maupun kualitatif terhadap tingkat pencapaian kinerja para individu dalam organisasi.

\section{Konsep Motivasi}

Sumber daya manusia yang bekerja dalam suatu organisasi tentu diarahkan untuk menapai tujuan, yaitu tujuan organisasi. Meskipun demikian, seseorang yang bekerja dalam suatu organisasi pasti memiliki tujuan pribadi yang ingin dicapai dalam pekerjaannya. Tujuan pribadi yang ingin dicapai seseorang dalam konteks "alasan" mengapa dia bekerja adalah merupakan motivasi yang mempengaruhi kinerjanya. Seperti dikatakan Terry yang dikutip oleh (Mo ekijat, 2002) motivasi merupakan keinginan di dalam diri seorang individu yang mendorongnya untuk bertindak. Dalam buku yang sama (Moekijat, 2002) mengatakan bahwa motivasi mempunyai arti yang sama dengan motif, yaitu suatu daya dorong atau perangsang untuk melakukan sesuatu. Artinya 
motivasi tidak akan muncul pada diri seseorang jika tidak dirasakan rangsangan Apabila motivasi telah tumbuh, maka dapat dijadikan bagi orang tersebut untuk menapai tujuan.

Motivasi merupakan subyek yang sangat penting bagi para pimpinan, karena mereka harus mampu mempengaruhi sumber daya manusia yang berada dalam lingkup organisasi yang dipimpinnya agar mereka dapat memenuhi baik tujuan pribadi juga dapat digerakkan secara bersama-sama untuk mencapai tujuan organisasi. Seperti dikatakan (Armstrong, 1994), bahwa motivasi muncul dalam dua cara. Pertama, orang dapat memotivasi dirinya sendiri dengan mencari. menemukan dan melakukan pekerjaan yang membawa mereka pada harapan bahwa tujuan mereka akan tercapai. Motivasi ini disebut dengan "instrinsic motivation". Kedua, orang dapat dimotivasi oleh pimpinan melalui beberapa metode seperti gaji, promosi dan penghargaan. Motivasi ini disebut: "extrinsic motivation". (Gitosudarmo et al., 2000) menjelaskan bahwa proses timbulnya motivasi merupakan gabungan dari konsep kebutuhan, dorongan, tujuan dan imbalan. Para pegawai dalam suatu lingkup pekerjaan akan bekerja dengan giat dan bersemangat apabila memiliki motivasi kerja yang tinggi. Oleh para pegawai tersebut motivasi dijadikan sebagai daya dorong dalam rangka memenuhi kebutuhan akan terapainya prestasi kerja. Seseorang yang memiliki motivasi kerja tinggi, biasanya akan terlihat dari capaian prestasi kerjanya. Memperhatikan uraian di atas, dapat disimpulkan bahwa motivasi merupakan rangkaian sikap yang mendorong atau menggerakkan individu-individu untuk mencapai tujuan. Karena berkaitan dengan sikap dan tingkah laku, maka tindakantindakan yang dilakukan dalam konteks mencapai tujuan tersebut harus selalu diawasi dan diarahkan agar dalam melaksanakan tugas tidak bertentangan dengan norma atau sistem nilai dan segala ketentuan yang ada dalam kehidupan berorganisasi.

\section{Sumber Daya Manusia dalam Organisasi}

Berbicara tentang organisasi adalah membahas tentang sebuah eksistensi.
Pemikiran tersebut muncul karena kenyataannya organisasi adalah sesuatu yang abstrak sulit dilihat tapi bisa kita rasakan eksistensinya hampir dalam semua aspek kehidupan. Karena sifat abstrak yang dimiliki oleh organisasi, menyebabkan manusia sering tidak menyadari bahwa mereka sudah berada dalam lingkungan organisasi sejak kecil yaitu keluarga. Sebagai sebuah sistem, organisasi dibentuk dari unsur-unsur yang sangat penting agar organisasi dapat berjalan sebagaimana mestinya. Unsur-unsur tersebut adalah manusia, kerjasama, tujuan bersama, peralatan, lingkungan dan sumber daya alam, memiliki ketergantungan satu sama lain, sehingga apabila terjadi perubahan pada unsur yang satu, maka akan berpengaruh pada unsur yang lain. Kondisi tersebut selanjutnya dapat dijadikan acuan bahwa dalam menilai keberhasilan suatu organisasi tidak bisa dilakukan secara sepotongsepotong, atau dengan kata lain harus melihat secara keseluruhan terhadap rangkaian tiap unsur yang berada dalam sistem tersebut. Meski memiliki saling ketergantungan sama lain, namun sumber daya manusia merupakan unsur paling utama yang menjadi faktor penggerak dalam suatu organisasi untuk mencapai tujuannya.

Pada dasarnya setiap organisasi akan berupaya tetap unggul dalam menghadapi situasi persaingan yang keras serta tuntutan dan keinginan para pemangku kepentingan. Agar dapat memenuhi semua tuntutan tersebut, maka sumber daya manusialah yang menjadi andalan utamanya. Melihat pentingnya peran sumber daya manusia dalam mengembangkan organisasi, maka mereka perlu dikelola dengan sebaik-baiknya melalui berbagai tindakan yang efektif, pengambilan keputusan yang memenuhi rasa keadilan serta penerapan kebijakan yang tetap memperhatikan hak-hak mereka.

Saat ini makin disadari bahwa kompetisi antar organisasi bukan terletak pada berapa besar "natural and capital resources" yang dimiliki, tapi telah beralih kepada "nilai" sumber daya manusia yang akan mengelola sumber daya lainnya. Seperti dikatakan oleh Thomas (1993:259) yang dikutip oleh (Soeling, 2003), bahwa perbedaan memiliki orang yang tepat, 
yaitu memiliki ketrampilan dan motivasi yang diperlukan, dan orang yang salah sangat luar biasa. Oleh karena itu merupakan tantangan bagi organisasi agar mampu menciptakan dan membudayakan nilai-nilai untuk menjadi nilai yang disepakati, dipahami dan dihayati dalam hati dan pikiran segenap orang dalam organisasi.

(Werther \& Davis, 1996) mengatakan, "The purpose of human resource management is to improve the productivity contribution of people to the organization in ways that are strategically, ethically and socially responsible". (Tujuan manajemen sumber daya manusia adalah untuk meningkatkan kontribusi produktifitas manusia kepada organisasi dengan cara yang strategis, etis dan bertanggung jawab secara sosial). Suatu organisasi yang percaya terhadap kemampuan sumber daya manusia yang dimilikinya tentu akan memberdayakan mereka dengan wewenang dan tanggung jawab yang besar, agar mereka bisa melakukan pekerjaan sesuai ruang lingkup yang telah disepakati sebelumnya dan membuat keputusan yang dapat mempengaruhi hasil kerjanya. Bruce Meglino dkk dalam Carell et.al. (1997:100), seperti dikutip oleh (Soeling, 2004) empat tipe nilai yang berkaitan dengan orang-orang dalam pekerjaannya, yaitu, 1. Achievement, yaitu tipe bekerja keras untuk mencapai keberhasilan meski harus menempuh berbagai kesulitan; 2. Concern for helping others, yaitu tipe yang sangat memperhatikan orang lain dan sangat berminat membantu mereka; 3 . Honesty, yaitu tipe yang selalu berkata jujur pada saat berhubungan dengan orang lain; 4 . Fairness, yaitu tipe untuk selalu melakukan apa yang dianggap adil dan tidak memihak dalam setiap kegiatan. Kategori empat tipe nilai di atas tentunya tidak boleh berhenti dan harus dikelola sepanjang waktu agar dapat dijadikan pedoman bagi setiap orang di dalam organisasi dalam bersikap, bertindak dan berperilaku.

\section{Hipotesis}

Menilik kajian teori dari para pakar bidang Manajemen Sumber Daya Manusia di atas, penulis belum melihat adanya hubungan yang signifikan antara pemberian punishment dengan motivasi atau dengan kata lain, bahwa sifat negatif punishment pada dasarnya tiidak bisa memotivasi seseorang untuk menjadi lebih baik. Sebaliknya, karena sifatnya yang positif maka pemberian reward dari pimpinan ataupun instansi akan berpengaruh secara signifikan terhadap motivasi pegawai. Kedua hal tersebut menjadi hipotesis dalam penulisan makalah ini.

\section{METODOLOGI PENELITIAN}

Metode penelitian yang digunakan adalah metode kuantitatif dengan pendekatan analisis deskriptif. Lokasi penelitian adalah Kantor Pusat Pendidikan dan Pelatihan Perdagangan, Jalan Abdul Wahab Nomor 38, Kedaung, Depok. Populasi dalam penelitian ini adalah seluruh pegawai yang ada di Kantor Pusdiklat Perdagangan Depok sebanyak 127 pegawai. Sampel yang digunakan pada penelitian ini sejumlah 58 karyawan dengan menggunakan teknik pengambilan sampel proportional random sampling. Data penelitian ini, diperoleh dari dua sumber, yaitu data primer dan data sekunder. Data primer adalah data yang diperoleh langsung dari sumbernya atau responden melalui kuesioner sedangkan data sekunder adalah data yang diperoleh secara tidak langsung melalui buku-buku, jurnal, dan laporan-laporan penelitian terdahulu. Analisis data dilakukan dengan menggunakan analisis regresi berganda. Regresi berganda adalah model regresi yang melibatkan lebih dari satu variabel bebas. Variabel terikat/ dependen dalam penelitian ini (Y) adalah motivasi pegawai sedangkan variabel bebas/ independen dalam penelitian ini adalah reward (X1) dan punishment (X2). Instrumen penelitian yang digunakan adalah kuisioner penelitian yang telah diuji validitas dan reliabilitasnya.

\section{HASIL DAN PEMBAHASAN}

Pusdiklat Perdagangan merupakan suatu unit organisasi setingkat eselon 2 (dua) di bawah payung Kementerian Perdagangan. Sesuai Permendag Nomor 08 Tahun 2016 tentang Organisasi dan Tata Kerja Kementerian Perdagangan RI, Pusdiklat memiliki tugas 
pokok dan fungsi melaksanakan pembinaan, bimbingan dan pengembangan pendidikan dan pelatihan pegawai dan SDM Sektor Perdagangan. Dalam menjalankan tugas pokok dan fungsinya, Pusdiklat Perdagangan membawahi tiga unit setingkat eselon 3 (tiga) yang menangani bidang kediklatan, yaitu Bidang Diklat Aparatur, Bidang Diklat Non Aparatur dan Balai Diklat Penguji Mutu Barang, serta satu unit yang menangani Tata Usaha. Seperti disampaikan sebelumnya, bahwa sesuai dengan tujuan yang ingin dicapai dalam penelitian, maka penelitian ini menggunakan pendekatan kuantitatif dengan teknik pengambilan sampel yaitu proportional random sampling, pengumpulan data menggunakan kuesioner, analisis data menggunakan analisis deskriptif, pengujian instrumen menggunakan uji validitas dan reliabilitas.

\section{Uji Validitas dan Reliabilitas}

Menurut Arikunto (2010) validitas adalah suatu ukuran yang menunjukkan tingkat ketepatan atau kesahihan suatu instrumen. Pengujian validitas dalam penelitian ini adalah dengan menghitung korelasi diantara masing-masing pernyataan dengan skor total menggunakan korelasi Pearson. Syarat minimum untuk dianggap valid adalah nilai rhitung $>$ dari nilai rtabel. Hasil uji validitas menunjukkan bahwa terdapat 14 (empat belas) pernyataan dari kuesioner mempunyai nilai $r$ (koefisien korelasi) lebih besar dari 0,3, sehingga 14 (empat belas) instrumen pada penelitian ini dikatakan valid dan layak divjikan.
Pengujian reliabilitas digunakan untuk mengetahui apakah pernyataan dalam kuesioner reliabel, artinya menunjukkan sejauh mana item pernyataan yang digunakan dapat dipercaya dan dapat diandalkan untuk digunakan sebagai alat ukur dalam penelitian. Pengukuran reliabilitas dilakukan dengan menggunakan koefisien alpha Cronbach (a). Variabel dikatakan reliabel jika Alpha cronbach memiliki nilai lebih besar dari 0,6 (Arikunto, 2010).

$$
\mathrm{rac}_{\mathrm{ac}}=\left(\frac{\mathrm{k}}{\mathrm{k}-1}\right)\left[1-\frac{\Sigma \sigma \mathrm{b}^{2}}{\sigma \mathrm{t}^{2}}\right]
$$

Keterangan:

rac $=$ koefisien reliabilitas alpha cronbah

$\mathrm{k}=$ banyak butir pertanyaan

$\Sigma \sigma_{b}{ }^{2}=$ jumlah varians per butir

$\Sigma \dagger^{2}=$ jumlah varians seluruhnya

Perhitungan Uji reliabilitas alpha Cronbach pada penelitian ini disajikan dalam persamaan berikut:

$$
\begin{gathered}
r_{a c}=\left(\frac{14}{14-1}\right)\left[1-\frac{13.429}{59.721}\right] \\
r_{a c}=(1.0769)[0.7751] \\
r_{a c}=0.8347
\end{gathered}
$$

Hasil uji reliabilitas didapatkan koefisien alpha Cronbach sebesar 0,8347. Nilai tersebut lebih besar dari 0,6 artinya kuesioner sebagai instrumen pada penelitian ini dikatakan reliable atau konsisten.

\section{Hasil Analisis Regresi Berganda} Tabel 1. Summary Output

\begin{tabular}{lrrrrr}
\hline \multicolumn{2}{c}{ Regression Statistics } & & & \\
\cline { 1 - 2 } Multiple R & 0.627277 & & & \\
R Square & 0.393476 & & & \\
Adjusted R Square & 0.371012 & & & \\
Standard Error & 0.154093 & & & & \\
Observations & 57 & & & & \\
\hline ANOVA & & & & & \\
\hline
\end{tabular}




\begin{tabular}{|c|c|c|c|c|c|c|c|c|}
\hline Regression & 2 & 0.831825 & 0.415913 & 17.51595 & $1.37 \mathrm{E}-06$ & & & \\
\hline Residual & 54 & 1.282219 & 0.023745 & & & & & \\
\hline \multirow[t]{3}{*}{ Total } & 56 & 2.114044 & & & & & & \\
\hline & & St andard & & & & Upper & Lower & Upper \\
\hline & Coefficients & Error & t Stat & P-value & Lower 95\% & $95 \%$ & $95,0 \%$ & $95,0 \%$ \\
\hline Intercept & 1.2319 & 0.232914 & 5.289074 & $2.28 \mathrm{E}-06$ & 0.764935 & 1.698865 & 0.764935 & 1.698865 \\
\hline X V ariable 1 & 0.406429 & 0.119872 & 3.390535 & 0.001311 & 0.166101 & 0.646757 & 0.166101 & 0.646757 \\
\hline X V ariable 2 & 0.096755 & 0.102315 & 0.945651 & 0.348539 & -0.10838 & 0.301885 & -0.10838 & 0.301885 \\
\hline
\end{tabular}

Berdasarkan hasil uji hipotesis dengan menggunakan analisis regresi berganda dengan menggunakan aplikasi Microsoft excel yang dapat dilihat pada Tabel 1. Hasil pengujian hipotesis menunjukkan $t$ hitung pada variabel reward (X1) adalah sebesar 3,3950, lebih besar daripada † tabel (maksimum t tabel adalah 2 (dua)). Hal ini menunjukkan adanya pengaruh yang signifikan dari variabel reward terhadap motivasi. Berdasarkan hasil analisis, koefisien variable X1 (reward) adalah sebesar $0.40 \mathrm{Hal}$ ini berarti, apabila variable $X 1$ meningkat sebesar $1 \%$ maka variable dependen (Y) akan meningkat sebesar $0.40 \%$. Sedangkan + hitung pada variabel punishment (X2) adalah sebesar 0,9456 lebih kecil daripada $t$ tabel, hal ini menunjukkan bahwa pengaruh variabel punishment (X2) terhadap motivasi adalah rendah (kurang signifikan). Berdasarkan hasil analisis, koefisien variable X2 (punishment) adalah sebesar 0,096 . Hal ini berarti, apabila variable X2 meningkat sebesar $1 \%$ maka variable dependen (Y) akan meningkat sebesar $0.096 \%$. Nilai $R$ square sebesar 0,39 atau $39 \%$. Artinya bahwa variabel reward dan punishment memberikan kontribusi terhadap variabel motivasi sebesar $39 \%$ sedangkan sisanya $61 \%$ variabel motivasi dipengaruhi oleh variabel-variabel lain yang tidak dibahas dalam penelitian ini, misalnya kompensasi yang memadai, kepemimpinan, lingkungan kerja dan lain-lain.

Mengutip pendapat para ahli, bahwa terdapat beberapa faktor eksternal yang dapat mempengaruhi motivasi, antara lain : a) Lingkungan kerja yang menyenangkan; b) kompensasi yang memadai; c) supervisi yang baik, d) status dan tanggung jawab; e) peraturan yang berlaku. Sedangkan faktor internal yang dapat mempengaruhi motivasi pada diri seseorang antara lain : a) kematangan pribadi; b) tingkat pendidikan; c) keinginan dan harapan pribadi; d) kebutuhan dan e) kelelahan dan kebosanan. Apabila diperhatikan, bahwa semua faktor yang mempengaruhi motivasi, baik eksternal maupun internal bersifat positif, artinya seseorang lebih termotivasi dengan hal-hal yang positif, dan hanya satu yang sifatnya negatif yaitu kelelahan dan kebosanan. Pendapat tersebut menunjukkan relevansi atas hasil penelitian ini, mengapa reward yang merupakan reinforcement positif memberikan pengaruh yang kuat dan signifikan terhadap motivasi (sebesar 0.40\%), sebaliknya punishment yang merupakan reinforcement negatif kurang mempengaruhi motivasi (sebesar 0.096\%).

\section{KESIMPULAN}

Berdasarkan hasil pembahasan pada makalah dengan judul "Analisis Pengaruh Penerapan Reward dan Punishment terhadap Motivasi Pegawai di Pusdiklat Perdagangan" dapat disimpulkan bahwa:

1. Hasil survey dengan responden pegawai Pusdiklat Perdagangan menunjukkan bahwa reward memiliki pengaruh yang signifikan terhadap motivasi mereka. Meski demikian patut disayangkan sampai saat ini Pusdiklat belum memiliki kegiatan lingkup internal yang berkaitan dengan reward.

2. Hasil survey dengan responden pegawai Pusdiklat Perdagangan menunjukkan bahwa penerapan punishment kurang berpengaruh terhadap motivasi mereka. Kesimpulan ini diperkuat dengan kondisi sebenarnya yang terjadi bahwa meski punishment dalam bentuk pemberian hukuman disiplin sudah dijalankan dengan 
sangat baik dan sesuai aturan yang berlaku di Pusdiklat Perdagangan, namun tetap terjadi pelanggaran disiplin yang dilakukan secara berulang oleh pegawai yang sama.

3. Apabila dilihat hasil survey kedua variable X1 dan X2 (reward dan punishment) terhadap variable $Y$ (motivasi) menunjukkan bahwa reward lebih berpengaruh terhadap motivasi dibandingkan dengan punishment. Namun dari nilai $R$ square yg rendah menunjukkan bahwa variabel reward dan punishment sesungguhnya bukan merupakan satu-satunya variabel yang paling mempengaruhi motivasi. Dengan kata lain terdapat variabel-variabel yang tidak dibahas dalam penelitian ini, (misalnya kompensasi, kepemimpinan, lingkungan kerja dan lain-lain) yang mungkin sangat mempengaruhi motivasi pegawai Pusdiklat Perdagangan

\section{REKOMENDASI}

1. Untuk skala internal, merekomendasikan kepada pimpinan Pusdiklat Perdagangan agar menginisiasi dibentuknya kegiatan internal yang berkaitan dengan pelaksanaan reward dengan tujuan memberikan apresiasi kepada pegawai hingga level terbawah. Kegiatan dimaksud bisa dilaksanakan 2 kali dalam setahun, misalnya: kegiatan pemilihan pegawai terbaik di lingkungan Pusdiklat Perdagangan untuk semester I dan II Tahun 2020. Apresiasi bisa diberikan dengan memasang foto pegawai terbaik tersebut di lobby ruang tamu serta hadiah kuota internet setiap bulan selama 6 bulan.

2. Terkait peranannya sebagai unit pembina SDM di lingkungan Kementerian Perdagangan, maka Biro Organisasi dan Kepegawaian perlu mengkonkritkan suatu kegiatan yang merupakan implementasi penerapan reward, yang tata cara pelaksanaannya diselaraskan dengan program-program kompensasi yang ada pada peraturan UU No.5 Tahun 2014 tentang ASN (Aparatur Sipil Negara). Tujuannya adalah agar dapat memicu kegairahan kinerja dan produktifitas pegawai di lingkungan Kemendag.
3. Merekomendasikan kepada Biro Organisasi dan Kepegawaian agar dapat menginisiasi sebuah kegiatan yang merupakan bentuk penyatuan komitmen bersama, agar pelaksanaan reward dan punishment dapat dilaksanakan dalam koridor sistem yang baik serta menjamin bahwa reward yang diberikan bersifat konkrit (bermanfaat) dan punishment yang diberikan bersifat keras, tegas, dan tidak pandang bulu.

\section{DAFTAR PUSTAKA}

Arikunto, S., (1993). Manajemen Pengajaran. Jakarta: PT Rineka Karya.

Arikunto, S., (2010). Prosedur Penelitian : Suatu Pendekatan Praktek (Revisi V). Jakarta: PT Rineke Cipta.

Armstrong, M., (1994). Performance Management. London : Kogan Page Limited.

As'ad, Mohamad. (2004). Psikologi Industri. Yogyakarta:Liberty.

Gitosudarmo, Indriyo, Sudito, \& Nyoman, I. (2000). Perilaku Keorganisasian. Yogyakarta : BPFE UGM.

Handoko, T. H. (1995). Manajemen Personalia Dan Sumber Daya Manusia (2nd ed.). Yogyakarta : BPFE UGM.

Hasibuan, M. S. . (1996). Manajemen Dasar, Pengertian dan Masalah. Jakarta : Ghalia Indonesia.

Irianto, J. (2001). Manajemen Sumber Daya Manusia. Surabaya: Insan Cendekia.

Ivancevich, J. M., Konopaske, R., \& Matteson, M. T. (2006). Perilaku Manajemen dan Organisasi (W. Hardani \& B. A. Yoso (eds.); Jilid 1). Jakarta : Erlangga.

Koencoro, Galih D., (2013), Pengaruh Reward dan Punishment pada Kinerja (Survei pada Karyawan PT. INKA (Persero) Madiun, Jurnal Administrasi Bisnis, Volume 5, Nomor 2, Brawijaya.

Mangkunegara, A. P. (2000). Manajemen Sumber Daya Manusia dalam Perusahaan (Cetakan ke). Bandung: PT. Remaja Rosdakarya.

Manullang, M. . (1996). Dasar-Dasar Manajemen (Cetakan ke). Jakarta: Ghalia Indonesia.

Moekijat. (2002). Dasar-dasar Motivasi. 
Bandung : CV. Pionir Raya.

Mulyadi dan Setyawan, Johny (2001). Sistem

Perencanaan dan Pengendalian

Manajemen, Jakarta: Salemba Empat

Nugroho, B., (2006). Reward dan Punishment

(6/IV/Juni). Bulletin Cipta Karya,

Departemen Pekerjaan Umum.

Ratna, P., Vera dan Riyono, Bagus. (2017). Peran Ketidakpuasan Kerja terhadap Intensi Turnover Karyawan dengan Stabilitas Anchor Sebagai Moderator, Gadjah Mada Journal of Psychology, Volume 3 No.1, Yogyakarta.

Roestiyah, N. K. (1986). Didaktik/Metodik. Jakarta: Bina Aksara.

Sastrohadiwiryo, Siswanto. (2002). Manajemen Tenaga Kerja Indonesia. Jakarta: Bumi Aksara.

Tohardi, Ahmad. (2002). Manajemen Sumber Daya Manusia, Bandung: Mandar Baru

Soeling, P. D. (2003). Mewujudkan Organisasi Berbasis Nilai. Jurnal Administrasi Terapan, Juli-Oktober 2003.

Soeling, P. D. (2004). Meningkatkan Kinerja Sumber Daya yang Dimilikinya. Jurnal Administrasi Terapan, Maret-J uni 2004.

Werther, W. B. J., \& Davis, K. (1996). Human Resources and Personnel Management. Tokyo : Mac Graw Hill Koga Kusha. 